\title{
Troponin T, Cardiac Muscle
}

National Cancer Institute

\section{Source}

National Cancer Institute. Troponin T, Cardiac Muscle. NCI Thesaurus. Code C104220.

Troponin T, cardiac muscle (298 aa, $236 \mathrm{kDa}$ ) is encoded by the human TNNT 2 gene.

This protein plays a role in cardiac muscle contraction. 